\title{
Land Expropriation and Compensation Process Among Development Induced Displaced Households: The Case of Dejen Woreda Rural Kebeles
}

\author{
Demeke Siltan \\ Department of Social Work, College of Social Science and Humanities Ambo University, \\ Ambo, Ethiopia \\ Tel: 251-091-247-2914_E-mail: demekesiltan@yahoo.com/demekesiltan99@gmail.com
}

Received: January 18, 2019 Accepted: March 2, 2019 Published: March 6, 2019

doi:10.5296/ijsw.v6i1.14461ＵRL: https://doi.org/10.5296/ijsw.v6il.14461

\begin{abstract}
Development-induced projects are factor for involuntary migration to urban areas for the search of better employment raised the rate of vulnerability for socio-economic inequalities. The aim of this study was to explore land expropriation process and Compensation issues among development induced displaced households. The study employed mixed methods approach. Quantitative data were gathered through structured questionnaire and qualitative data were collected via interview and focus group discussion. By using Census survey a total of 162 displaced households participated in the study. The finding revealed that majority of the households $(87.8 \%)$ did not participate Invitation on public meetings $84.0 \%$ did not Participation in the land valuation process and almost all $95.5 \%$ did not Participation in inventory of Assets. In addition $85.9 \%$ of the respondents did not assume that the valuation process was transparent. The fining also revealed that the amount of money paid as compensation for the displaced households is not fair/ enough as compared with what they lose. Therefore the government should provide fair amount of compensation for households who lost their land because of deemed development projects.
\end{abstract}

Keywords: Land, Expropriation, Land valuation development induced, Compensation

\section{Introduction}

Development-induced projects that caused displacement of farmers with insufficient compensation for the lost farm lands is a factor for involuntary migration to urban areas for the search of better employment raised the rate of vulnerability for socio-economic inequalities (Siciliano, 2012 cited in Bikila, 2014). Beside to this, the rural poor having economic hardship in the rural life, lack of employment opportunities and limited future 
vision of working to way out from poverty are all the major problems faced by rural farmers. They are forced to change their livelihood strategy which will be new for them and difficult to adapt and they will obliged to migrate for searching job in urban areas (ILO, 2008 cited in Gebre, 2013).

In Ethiopia, development induced displacement is becoming a great concern in different parts of the country at different level. Displacements aiming at the extension of irrigation and hydropower production referred to as dam induced displacement, provision of better housing in urban centers, large scale agriculture investment projects, and conservation of wildlife via national parks are the major causes of displacement in Ethiopia (Irit \& Weyni, 2011)

According to the current constitution of Ethiopia, land is owned by the state and people have only the right to use (FDRE, 1994). The constitution states that: The right to ownership of rural and urban land, as well as of all natural resources, is exclusively vested in the State and in the peoples of Ethiopia. Land is a common property of the Nations, Nationalities and Peoples of Ethiopia and shall not be subject to sale or to other means of exchange.

In Dejen Woreda, because of development projects, farm land is taken from the rural households and it is the cause for the evacuation of about 162 rural households from their farm land. From the kebeles' of the woreda, three kebeles namely Gelgele, Qoncher, and Zemetin are exposed of the problem and more than 85 hectare of farm land is taken from this farmers and it brings about an impact on the livelihoods of the households since these households livelihood is extremely depends up on agriculture.

In relation to compensation, according to FDRE Proclamation No. 456/2005, 'holder of rural land who is evicted for purpose of public use shall be given compensation proportional to the development he, has made on the land and the property acquired, or shall be given substitute land thereon. Where the rural landholder is evicted by federal government, the rate of compensation would be determined based on the federal land administration law. Where, the rural land holder is evicted by regional governments, the rate, of compensation would be determined based on the rural land administration laws of regions'. But practically those evicted farmers neither given fair amount of compensation nor substitute land thereon from the regional and federal government after eviction from their farm land.

This study therefore, is intended to examine land expropriation process and compensation issue among development induced displaced households the case of Dejen woreda in rural that has been unnoticed by ant of preceding researchers. This study has the following research objectives; examine the land expropriation process of the displaced households, and compensation issues of displaced households.

\section{Material and Methods}

The study was carried out in 2016/2017 in Dejen woreda, (Figure 1 below). The study area is located in Eastern Gojjam Amhara regional state of Ethiopia, $229 \mathrm{~km}$ far from the capital city of the country, Addis Ababa. Majority of the population of the study area are highly dependent on agricultural especially production of crop such as teff, wheat maize, sorghum, and others and animal rearing as a supplementary livelihood strategy.

To undertake this study, mixed research design was employed. Specifically case control mixed method design was applied. Three major approaches were used in data collection. First, 


\section{Macrothink}

International Journal of Social Work

ISSN 2332-7278

2019, Vol. 6, No. 1

three focused group discussions were carried out, household, another from non-displaced households and third from both (displaced and non-displaced households) has been conducted. In the focus group discussion, 24 farmers, eight household heads in each three groups participated in the discussion

In-depth Interview: it was another way of data collection instrument for this research; by using this instrument, the researcher has got more information in greater depth from informants. The researcher has interviewed seven individuals (three elders, two youths one male and female, one valuation expert and one female headed household) the researcher tried to keep interview till the data get saturated.

Census survey sampling procedure has been used to select 162 displaced households from three study sites (Gelgele Zemetin and Qoncher (Figure 1 and Table 1). The survey was carried out using a standard questionnaire with structured and non structured questions relevant to the study. The questionnaires were developed and tested during a pilot survey. Data were analyzed using statistical package for social scientists (SPSS) and excel with a general framework of contrasting the assets and livelihood strategies for both groups of households studied.

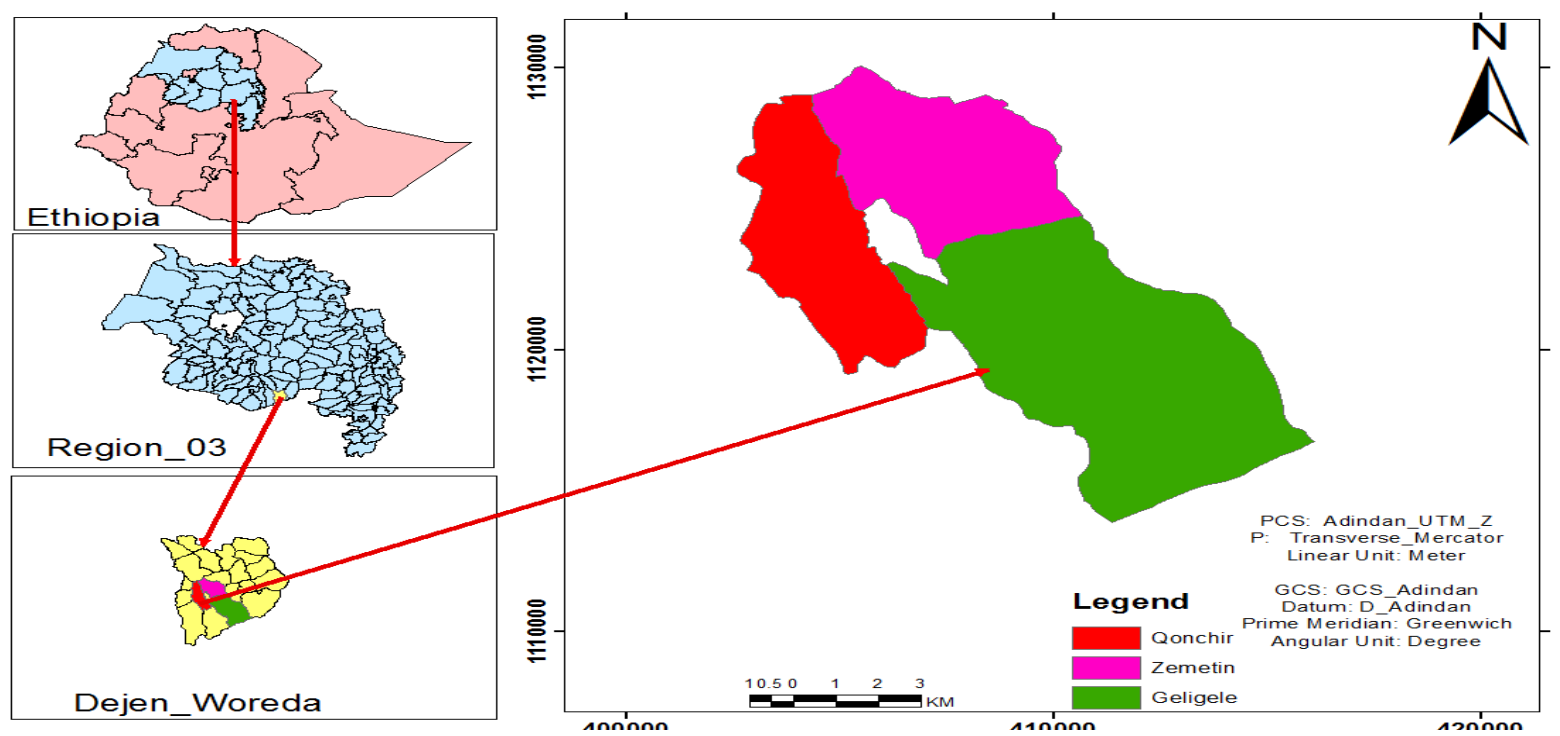

Figure 1. Map of the study area

\section{Results of the Study}

\subsection{Socio Demographic Characteristics of Respondents}

The socio demographic characteristic of the sample households is presented at the following table. 
Table 1. Background characteristics of respondents $(\mathrm{N}=156)$

\begin{tabular}{|c|c|c|}
\hline \multirow[t]{3}{*}{ Sex of respondents } & & $\%$ \\
\hline & Male & 76.3 \\
\hline & Female & 23.7 \\
\hline \multirow[t]{2}{*}{ Marital status } & Married & 87.2 \\
\hline & Others & 12.8 \\
\hline \multirow[t]{2}{*}{ Age of respondent } & $25-50$ & 59.0 \\
\hline & Greater than 50 years & 41.0 \\
\hline \multirow[t]{2}{*}{ Educational status } & Illiterate & 81.4 \\
\hline & Literate & 18.6 \\
\hline \multirow[t]{2}{*}{ Family size } & $1-5$ & 50.6 \\
\hline & $6-10$ & 49.4 \\
\hline \multirow{2}{*}{$\begin{array}{l}\text { № of individual that had } \\
\text { economic contribution }\end{array}$} & $1-4$ & 78.1 \\
\hline & $5-8$ & 20.5 \\
\hline
\end{tabular}

Source: household survey, 2017.

Table 1 reveals the socio-demographic characteristics of the respondents. In terms of sex composition of respondents, $76.3 \%$ households were males and $23.7 \%$ households were females. $87.2 \%$ households are married whereas $12.8 \%$ households are single, divorced and widowed. In terms of age composition 59.0\% households are found in age range of 26-50 and $41 \%$ households were found above 50 years of age. In terms of educational status $81.4 \%$ households are illiterate whereas $18.8 \%$ households are literate. In the case of family size $50.6 \%$ of households have $1-5$ member in their family whereas $49.4 \%$ of households have 6-10 family members in their household

\subsection{Compensation and Land Expropriation Process}

Compensation refers to specific measures intended to make good the losses suffered by people displaced and/or negatively affected by the acquisition. Compensation usually takes the form of a one-off payment, either in cash or in kind and is principally about awards to negatively affected persons (Anuar et al., 1998 cited in Gashaw, 2015) but in the study area compensation was done only in cash (money). And under this section various issues such as invitation on public meetings, about expropriation of farm land, the participation of households on the valuation process and transparency of the valuation process is discussed. 
Table 2. Percentage distribution respondents by the participation of households on public meetings, valuation process, asset inventory and transparency of the valuation process $(\mathrm{N}=156)$

\begin{tabular}{lll}
\hline & Yes & No \\
& $\%$ & $\%$ \\
\hline Invitation on public meetings & 12.2 & 87.8 \\
Participation in the land valuation process & 16.0 & 84.0 \\
Participation in inventory of Assets & 4.5 & 95.5 \\
Transparent of the valuation process & 14.1 & 85.9 \\
\hline
\end{tabular}

Source: household survey, 2017.

Table 2 reveals that invitation of households on a public consultation/discussion about expropriation of their farm land and only $12.2 \%$ of the households were invited for discussion and large number of respondents' $(87.8 \%)$ were not invited for public discussion during expropriation of the farm land of the households

The other row discloses about households participation on the valuation process of land expropriation and only $16 \%$ of the households participate in the valuation process whereas large number of households $(84.0 \%)$ didn't have the chance to participate in the valuation process of their farm land. The participation of the households at the time of inventory of the asset of the households was also in question. $95.5 \%$ of the respondents didn't participate in the inventory of the asset of the households only $4.5 \%$ of the households participate during asset inventory.

The last row of the table elucidates whether the valuation process was transparent or not and for $85.9 \%$ of the respondents the valuation process was not transparent at all and $14.4 \%$ of the households respond the valuation process was transparent.

Discussants also confirmed that there was no any formal public meeting related to land expropriation. No community member had been consulted and asked on the interest. The concerned body from the woreda came to the kebele and they told them their land is going to be taken by government for development project and there was no room for discussion about the issue of land that has been expropriated. It was already decided by the concerned body but the households' state that there has to be a time for preparation, a discussion and public meeting before land is expropriated.

Displaced discussants added that:

There was no meeting or discussion regarding to land expropriation. But before expropriation there has to be discussion and at least they have to know our position concerning our land. It was so good for preparation if they tell us before two or three years; but they told us 'the land is needed for investment and as you know land is for the government, the government need it for mega project, so you have to accept it because it comes from the government and you will get appropriate compensation for what you will lose.

By doing so, discussants stated that they don't have any options except accepting the decision 
of the government and finally they accept it. Hence it implies there was no any public meeting and discussion when land is expropriated from the households.

The other important thing is about the valuation process; according to discussants and informants, after they know that the land is going to be taken by government for development projects, woreda administrators select elders from the locality that can serve as a witness during valuation and measuring the land but, for the discussants the elected elders were serving nothing, they were symbols and did nothing in the valuation process. Everything was done by those individual who came from the woreda land administrators; they did it as they want. Therefore there was no any kind of participation of the community in general and households who lost farm land in particular in the valuation process the land they lost. The valuation process in general was not satisfactory to them and they told me that it better to say 'they kill us'.

In contrast to this Mr Mekuria, the land valuator of the woreda stated that:

There was no that much problem on the valuation process land. While valuating the land even we always add some value on the land. For example the expropriated land will be 1.25 ha and while we calculate the amount of money for compensation, we calculate it by making it 1.5 ha. Hence I haven't seen that much problem on the valuation of land

Another major important point was about the transparency of the valuation. For Zemetin kebele, discussants and informants, the valuation of land was not transparent totally. As it is already stated the valuation was done by land administrator of the woreda without the involvement of the farmers. Ato Abeje on the transparency of valuation process stated that:

The kebele administrators bring a stamped paper from the woreda and every household who lost farm land was called and the chair man of the kebele told them the amount of money they are going to get as compensation; Then, they went to the woreda to take their money but there was dissimilarity in the amount of money between what the chair man of the kebele said to them and the woreda. After all we refused to receive the money and appointed for another but on the other day the woreda told them it was the mistake of the chairman of the kebele not the woreda. Then, the entire householder decided to take theire money. There is an Amharic

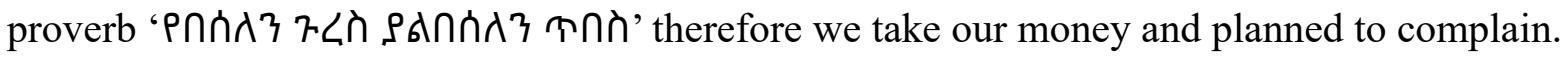

Therefore the valuation totally lacks transparency and Debasu has also expressed the following about the transparency of the valuation process:

I have lost 2 ha of farm land because of Dashin cement industry. It was the only farm land that I had in the kebele it has been everything for me (source of food for my family even for my cattle, to teach children and the like). The amount of money that I have to get was valued around 500,000 ETB but I have got only 200, 000 ETB that means I have lost around 300,000 ETB, and then what can I do by that money? Nothing as you are looking at me I am aged and am around 75 years of age. So I couldn't do something. If it can buy a house around the town it was very helpful for me to rent it and live on it;. I don't know where the money is right now; the money is already lost for buying salt and pepper and now I have nothing. You know walking dead I am like that. Therefore the valuation lacks transparency.

Displaced respondents were asked about the type of compensation they got from the 
government (in kind or in cash) and all the households who lost their farm land paid in cash as compensation. Informants and discussants also affirm me that the mode of compensation was in cash this is because there is no any alternative farm land that could be given for households as compensation.

\subsubsection{Fairness of the Compensation}

Table 3. Percent distribution of displaced households on fairness of the compensation

\begin{tabular}{ll}
\hline & Percent \\
\hline Yes & 3.8 \\
No & 96.2 \\
\hline
\end{tabular}

Source: household survey 2017.

Table 3 disclose about the fairness of the compensation they got and for only $3.8 \%$ of the households the compensation was fair or it was enough to them but for large number of respondents $(96.2 \%)$ of respondents didn't believe that the compensation they got was not fair or it was not enough to them when it is compared with what they lost.

According to informant and discussants in all kebeles the amount of money they gave them as compensation was not enough, they state that they gave them by calculating for only ten year; as discussants told me the compensation was not totally enough when it is compared with what they lose. Displaced discussants of two kebele's zemetin and gelgele state that:

The most important resource in the locality is farm land. Money is not as important as farm land, you can finish a lot of money within a day, but if you have land you might produce whatever grain you gave for your land, you may rent or sharecrop it and get it back after a year. If you have land you are guaranteed at least for a year but that is already a dream. We lost our farm land but still we are paying the tax for the government even the tax is not exempted from us. They gave us by calculating for only ten years and it is almost ten year that we lost our farm land. We thought we will renew our contract after ten year but it is impossible.

The land valuator of the woreda (Mr Mekuria) also state that the amount of money given as a compensation for the households is not enough.

He added that:

We gave only money for the householders but it is incomparable with what they lose. We gave up to 250,000 ETB for a household and after a year you can't see any change on that household because they don't how to use money; they might drink alcohol or other and after some year everything will be lost. I will be very happy if the money is more than this So that I believe the money in not enough but we did that because it is the order of the government.

Hence it can be deuce that the amount of money they got was not enough when it is compared with what they lose.

Displaced households were also asked whether the compensation was paid timely or not and 
the result is summarized under Table 4.

Table 4. Percent distribution of displaced households whether the compensation was provided timely or not

\begin{tabular}{cl}
\hline & Percent \\
\hline Yes & 5.1 \\
No & 94.9 \\
\hline
\end{tabular}

Source: household survey, 2017.

Table 4 unveils whether the compensation for displaced households provided timely or not and only $5.1 \%$ of the household got their compensation timely but large number of households (94.9) didn't have their compensation on time.

Some of the discussants and informants agreed that the compensation was provided timely especially for the two kebeles (Zemetin and Qoncher). As they told me the compensation was provided timely. But it was quite different for Gelgele households; as they stated, after they agreed forcefully to leave their land for the project, the machine came and tries to start work and those households who lost their farm land start revolt against the project and after the revolt, the government start to give their compensation. Therefore there was variation in compensation payment

Table 5. Percentage distribution of displaced households on expressing dissatisfaction and receiving proper response from the responsible body

\begin{tabular}{lll}
\hline & Yes & No \\
& $\%$ & $\%$ \\
\hline Express dissatisfaction & 40.4 & 59.6 \\
Receiving proper response & 3.5 & 36.5 \\
\hline
\end{tabular}

Source: household survey, 2017.

Table 5 explains opportunities of expressing dissatisfaction about the compensation they got from the concerned body and $40.4 \%$ of the respondents had the opportunity of expressing their dissatisfaction towards the compensation they got and $59.6 \%$ of the households don't have any opportunity of expressing their dissatisfaction about the compensation they got because of the project. Among households who got the opportunity of expressing their dissatisfaction, they didn't get proper response from the concerned body

More over data from discussants and informants substantiate that there was opportunity for expressing dissatisfaction concerning compensation. Symbolically there was a committee which is formed at the woreda level to express the dissatisfaction of land holders towards the compensation issue and many households were dissatisfied with the compensation they paid. They have tried to express their dissatisfaction but no one got a proper answer from that 
committee rather those farmers were obliged to accept the decision made by the concerned body. Therefore in terms of expressing dissatisfaction there were committees but they were serving on behalf of the government not for the farmers.

3.2.2 Accessibility of Trainings and Technical Assistant and Follow-Up After Land Expropriation

Table 6. Percentage distribution displaced households on getting trainings and technical assistant and follow-up $(\mathrm{N}=156)$

\begin{tabular}{lll}
\hline & Yes & No \\
& $\%$ & $\%$ \\
\hline Getting trainings & - & 100.0 \\
Technical assistant and follow-up & - & 100.0 \\
\hline
\end{tabular}

Source: household survey, 2017.

Trainings are in fact vital for displaced households especially after they lost their most valuable asset i.e. farm land. The table above reveals whether there were trainings or not after households lost their farm land and as it is indicated in the table, there were no training for the households after they lost their farm land. The other is about technical assistance and follows up from the concerned body and there was no any technical assistance for the households from the concerned body it also explains there was any kind of follow up from the concerned body after households dispossessed form their farm land.

In addition to this, data from discussants affirms that there was no any kind of training regarding expropriation of farm land. They state that it was really good if there was training but the government only gave them money and go to their work.

Melese had his saying about trainings and follow ups:

We know nothing since we are farmers and illiterate. It was very important for the households if there were trainings by contextualizing the living condition of the community. Even some households had slaughtered two sheep in a day because we thought the amount of money we got as compensation was too much; this is the result of illiteracy and lack of trainings to the displaced households. After a year their money became lost. This is the result of lack of trainings and absence of follow up from the woreda.

But if there was training it was very important to them especially for leading their life. As they stated every household lacks how to lead their life. In addition to this there was no follow up from the responsible body; they simply gave them money and left them in their home and householders did as their mind orders them to do.

\section{Discussion}

This study has come up with the issue of compensation of displaced households which includes the participation of households in the public meeting, valuation process, and the participation of the households in the asset inventory. 
And the study discloses that majorities of the displaced households were not aware of, consulted and participated in any meeting regarding to exportation of farm land, they were not given enough time for preparation.

The UN Guidelines on Development-based Evictions and Displacement (2010 cited in Saba, 2016), require the following procedures has to considered prior to evictions: (a) appropriate notice to all potentially affected and evicted persons; (b) a reasonable time period for public review or commenting on the proposed plan; (c) opportunities for the provision of legal advice to persons about their rights and options and; (d) holding of consultations that provide affected persons and their advocates an opportunity to challenge the evictions or propose alternative.

When the finding is evaluated based on the UN guide line, the real that happens in the study area is quite different with the UN guide line. Households were not noticed about land expropriation, there was no meeting at all before expropriation, and also opportunity of getting legal advice was totally unthinkable.

Similarly FDRE proclamation No.455/2005, states that

expropriation of land holdings for public purposes and payment of compensation stated in part two under article 4(1) "where a woreda or an urban administration decides to expropriate a landholding, it shall notify the landholder, in written, indicating the time when the land has to be vacated and the amount of compensation to be paid."

However the applicability of the guide line and the proclamation was on the air. Households in the study area were not invited in public meeting before expropriation rather the woreda administration came to them and take their farm land then gave money as compensation

On the other hand previous studies show there was at least public meeting with regard to land expropriation and compensation issues. (Muhdin, 2016) reported that there was public meeting regarding to relocation though, households were not happy with relocation and leaving their residence, they have participated in such meetings. Many researchers also deduce that there was a greater problem in the valuation process and asset inventory. For instance (Belachew, 2007) reported that there was a greater inconsistency of valuation of asset between dislocated households. Therefore this study also comes up with problem of valuation, asset inventory as well transparency of the valuation that go along with previous researchers.

The finding unveils that there was no any benefit packages given for the households like trainings and services except giving money as compensation. Previous researchers affirm that there were promises to give post exportation trainings and services for the dislocated households though the concerned bodies don't go beyond promises. (Bikila, 2014) reported that displaced were promised to get trainings and organized in micro level enterprises of varies types right after displacement; that was suggested to be a solution to the joblessness of relocates. However, none of the promised trainings and social services provided after displacement. The same is true for this study

\section{Conclusion}

In relation to the expropriation process the finding reveals that households were not invited in any kind of discussion and meeting. It implies everything was decided by the government 
without taking in to consideration the land owners. Simply is done though the approach called top down approach. Majority of displaced households were not participated in the valuation process the land that has been expropriated. There were some representatives and committees that has been elected from the locality by the displaced households and their involvement was nothing they were puppets and the valuation process and asset inventory was done by the good will of the land administrators of the wereda and the valuation as well as the asset inventory was not totally transparent for the displaced households.

In terms of compensation, for some of the households, the compensation was provided timely and for other households there was delay in paying compensation.

Majority of displaced households believe that the amount of money they got as a compensation was not fair and enough when it is compared with what they lose

The other major findings of the study is about the trainings and follow ups that has been taken by the concerned body and the finding reveals that there was no any kind of training given for displaced households. The government simply take their land by the motto of land is for the government and gave them money as a compensation. Nobody gave them any training and also there was no follow up from the concerned body.

Finally this study reveals majority of the respondents respond that there was no that much discrimination based on gender age and disability and other issues. In addition to this there was no special attention for the most vulnerable group of the community which implies that everybody was treated equally.

\section{Implications of the Study}

As it is indicated on the analysis and presentation part, households in the study area are becoming victim of development projects. They have lost their farm land, livestock; their livelihood strategy and the living condition of displaced households become worse and worse. Therefore based on the finding of the study the following issues are forwarded as Implications for the concerned bodies.

\subsection{Implication for Social Workers}

The finding revealed that the households who lost their farm land are becoming victim of development projects and it need the intervention of social work practitioners especially macro social work practitioners. Social work practitioners can work as a planner enabler, catalyst, coordinator, and teacher of problem-solving skills and applied locality development model to bring about a change in collaboration with the local community.

In addition to this, the finding revealed that there was no pre and post expropriation training to the land holders. Therefore, social workers could provide locality oriented trainings (especially livelihood strategies) that can enable displaced households to cope up with the problem they are facing and it will be very helpful to rebuild their livelihoods easily.

\subsection{Implication for the Government}

The finding reveals that land holding size of the household is diminishing from year to year because of development projects and as a researcher I strongly believe that development is inevitable and I can't deny the importance of development projects but the project which is established in any site in needs to have some contribution to the local community. By any means it has to bring a benefit package for the households but there are no any benefit 
packages for the households except paying compensation.

The government should stop top down approach rather it has to listen the voice of the land holders before forcing them to leave their farm land with continuous meetings and discussions with the community before expropriation.

The finding also reveals that land expropriation process lacks transparency at all. Every process has to be in accordance with the law. The FDRE constitution says all persons who have been displaced or whose livelihoods have been adversely affected as a result of State program have the right to commensurate monetary or alternative means of compensation, including relocation with adequate State assistance. But the applicability of this article is zero. Therefore relocation process should be clear, transparent and fair and should be explained to those who will be affected in time. This would reduce the tendency of feeling maltreatment and they will be ready for their challenges.

The finding revealed that the amount of money paid as compensation is no fair therefore government should provide appropriate compensation for displaced households in addition to this, though there was some room for compliance, in practical, households who complain on the compensation didn't have proper answer from those officials. Rather they were forced to accept without any complain. Therefore the must be proper answer for compliances.

According to discussants the amount of money as compensation is given by calculating for ten consecutive years meaning according to their agreement the land is expropriated for ten years but after ten years there is no contract renewal. Hence the government with the investor should think over it and renew the contract after the contract is expired so as to benefit small holder farmers.

\subsection{Implication for Future Researchers}

This research is delimited on Dejen woreda rural kebeles and I recommend future researchers to incorporate large areas and it will be very helpful to generalization. Future researchers may do a research by selecting either of the three concepts (livelihood resources, strategies or outcome) and might come up with detail analysis since they can be an independent research.

\section{References}

Achamyeleh, G. (2014a). Peri-urban land rights in the era of urbanisation in Ethiopia: A property rights approach, 6(1), 120-138.

Achamyeleh, G. (2014b). Urbanization and the Struggle for Land in the Peri-Urban Areas of Ethiopia, 1-21.

Agerie, N. (2013). Determinants of Smallholder Rural Farm Households' Participation in Small Scale Irrigation and Its Effect on Income in North Gondar Zone: A Cross- Sectional Approach (Evidence from Dembia Woreda. Mekele University.

Belachew, Y. (2007). Expropriation, valuation and compensation practice in Ethiopia The case of Bahir Dar city and surrounding, 31(2), 132-158.

Bikila, A. (2014). The Impacts of Development-Induced Displacement and Relocation on the Livelihoods of Households in Dukem Area. Addis Ababa, Ethiopia.

Broughton, A. (2013). Land Grabbing: A New Colonialism, (April 2008), 25-29.

Cernea, M. M. (1997). Development induced and conflict-induced IDPs: bridging the 
research divide.

Cernea, M. M. (2000). Impoverishment Risks, Risk Management, and Reconstruction: A Model of Population Displacement and Resettlement By. Washington, DC., USA.

Cotula, L., Vermeulen, S., Leonard, R., \& Keeley, J. (2009). Land grab or development opportunity international land deals in Africa Land grab or development opportunity

Creswell, J. W. (2009). Research Design, Qualitative, Quantitative, and Mixed Methods Approaches (3rd ed.). Lincoln: Sage Publications, Inc.

Dejene, N. (2011). Rapid Urban Expansion and Its Implications on Livelihood of Farming Communities on Peri-Urban Area: The Case of Sebeta Town. Addis Ababa, Ethiopia.

Desalegn Keba. (2013). The Socio-Economic and Environmental Impacts of Large Scale (Agricultural) Land Acquisition on Local Livelihoods: Oslo Blinder, Norway.

Dhru, K. A. (2010). Acquisition of land for "development" projects in India: The Road Ahead. Gujarat, India.

Downing, T. E. (2002). Avoiding New Poverty: Mining-Induced Displacement and Resettlement. England.

ECA. (2014). Guiding principles on large scale land based investments in africa. Addis Ababa, Ethiopia.

Ellis, F. (2005). Small-Farms, Livelihood Diversification and Rural-Urban Transitions: Strategic Issues in Sub-Saharan Africa. Kent, UK.

Ellis, F., \& Allison, E. (2004). Livelihood diversification and natural resource access Livelihood diversification and natural resource access (No. 9). London.

Endeshaw, G. (2016). Impacts of Urban Renewal Induced Displacement and Resettlement on the Economic and Social Life of Displaced People: The Case of Yeka Ayat 2 Condominium. Addis Ababa, Ethiopia.

Etenesh, M. (2007). Impact of Development-Induced Displacement on Female Headed Households in Inner City Slum Areas of Addis Ababa: The Case of Sheraton Addis Expansion Project. Addis Ababa, Ethiopia.

Fekadu, K. (2014). The Rates and Effects of Urban Sprawl in Developing Countries: The Case of Addis Ababa, Ethiopia, 135-151. https://doi.org/10.2478/ijas-2014-0009

Feyera, A. (2005). Urban Expansion and the Livelihood of the Peri-Urban Agricultural Community: The Case of Addis Ababa.

Firew, B. (2010). The Impact of Horizontal Urban Expansion on Sub- Urban Agricultural Community Livelihood: The Case of Tabor Sub-City, Hawassa city, . Addis Ababa University, Addis Ababa.

Fitsum, R. (2008). Urban Redevelopment and Displacement in Arada Sub city Addis Ababa. Addis Ababa, Ethiopia.

Gashaw, T. (2015). Land Expropriation and Compensation Payment in Ethiopia: Review, 6(13), 93-98.

Gebre, Y. (2013). Urban Development and Displacement in Addis Ababa: The Impact of Resettlement Projects on Low-Income Households, 24(2), 53-77. 
Getu Ambaye and Assefa Abeliene. (2015). Development-Induced Displacement and Its Impacts on the Livelihoods of Poor Urban Households in Bahir Dar, North Western Ethiopia. Ahmr, 1(3), 310-331.

Gudeta, D. (2012). Socio-economic and Environmental Impact of Floriculture Industry in Ethiopia. Ghent University, Belgium.

Habtamu, A. (2014). The Impact of Urban Redevelopment-Induced Relocation on Relocatees Livelihood Asset and Activity in Addis Ababa: The Case of People Relocated Arat Kilo Area, 2(1), 43-50.

Irit, E., \& Weyni, T. (2011). Rebuilding livelihoods after dam-induced relocation in Koga, Blue Nile basin, Ethiopia. Bonn, Germany.

Israel, G. D. (2009). Determining Sample Size 1, 1-7.

Johnson, R. B., \& Onwuegbuzie, A. J. (2004). Mixed Methods Research: A Research Paradigm Whose Time Has Come, 33(7), 14-26.

Kothari, C. R. (2004). Research Methodology Methosds and techniques (Second Edi). Jaipur, India: New Age International.

Leulsegged, K., Dawit, A., Zeleke, G., Fisum, H., \& Andreas, H. (2015). Impact of Urbanization of Addis Abeba City on Peri-Urban Environment and Livelihoods.

Maartje van Eerd, B. B. E. (2013). Working Paper on Evictions, Acquisition, Expropriation and Compensation. Kenya, Nairobi.

Matthews, B., \& Ross, L. (2010). Research Methods, A practical guide for the social sciences. Mensah, K. K. (2014). Assessing the Livelihood Opportunities of Rural Poor. Kwame Nkrumah.

Mesfin, A. (2013). Effects of Large-scale agricultural investments on smallholder farming in Sub-Saharan Africa ( Case study : Ethiopia ), (June 2013).

Misikir, G. (2014). The effects of urban development activity on the relocated residents: the case of arada sub-city. Addis Ababa.

Moges, G. (2010). Effects of Large-scale Land acquisition in Rural Ethiopia: The Case of Bako-Tibe Woreda. Swidish University.

Muhdin, A. (2016). Development Induced Displacement In The Context of UN Guiding Principles and Au Convention:Experience From Addis Ababa City Urban Renewal Projects. Addis Ababa, Ethiopia.

Nampungu, P. (2011). An Assessment of the Impact of a Government Involuntary Relocation and Resettlement Program on the Livelihoods of Development-Induced Displaced Populations. Oxford Brookes University.

Obsa, T. (2013). Effect of Large-Scale Agricultural Investment on Local Livelihoods: A Study of Bako-Tibe Karuturi Agro Products Plc., Ethiopia. Norwegian University of Life Sciences (UMB), Ås, Norway.

Rahmato, D. (2011). Land to Investors: Large-Scale Land Transfers In Ethiopia.

Robinson, W. C. (2003). Risks and Rights: The Causes, Consequences, and Challenges of Development-Induced Displacement. 


\section{Macrothink}

International Journal of Social Work

ISSN 2332-7278 2019, Vol. 6, No. 1

Saba, S. (2016). Assessment of the Effects of Development Induced Displacement in Addis Ababa, Arada Sub City: The Case of Relocated Households of Basha Wolde Chilot No 1. Area. Addis Ababa, Ethiopia.

Saheed, Z. (2012). Externalities of Urban Redevelopment: Eviction, Relocation and Compensation in Nigeria, 3(5), 272-278.

Scoones, I. (1998). Sustainable Rural Livelihoods A Framework For Analysis (No. 72).

Sharp, K., Devereux, S., \& Amare, Y. (2003). Destitution In Ethiopia' S Northeastern Highlands (Amhara National Regional State ) Highlands (Amhara National Regional State ).

Stanley, J. (2004). Development-induced displacement and resettlement.

Teketel, F. (2015). Urban Expansion and Its Effects on Peripheral Farming Communities: The Case of Hosanna Town, Hadiya Zone, SNNPR, Ethiopia. Haramaya University, Haramay. Terminski, B. (2012). Development-induced displacement and human security: A very short introduction.

Terminski, B. (2013). Development-Induced Displacement and Resettlement: Theoretical Frameworks and Current Challenges.

Tesfa, T. (2014). The Effect of Development Induced Displacement on Relocated Household: The Case of Addis Ababa. Hague, Netherlands.

Yared, A. (2001). Food Security And Sustainable Livelihoods In Ethiopia. In Yared Amare (Ed.). Addis Ababa, Ethiopia: Forum for SocIal Studies.

\section{Copyright Disclaimer}

Copyright reserved by the author(s).

This article is an open-access article distributed under the terms and conditions of the Creative Commons Attribution license (http://creativecommons.org/licenses/by/3.0/). 